\title{
Seabird mortality from longline fishing in the Mediterranean Sea and Macaronesian waters: a review and a way forward*
}

\author{
JOHN COOPER ${ }^{1}$, NICOLA BACCETTI ${ }^{2}$, EDUARDO J. BELDA ${ }^{3}$, JOHN J. BORG ${ }^{4}$, \\ DANIEL ORO $^{5}$, COSTAS PAPACONSTANTINOU ${ }^{6}$ and ANTONIO SÁNCHEZ ${ }^{7}$ \\ ${ }^{1}$ Avian Demography Unit, Department of Statistical Sciences, University of Cape Town, Rondebosch 7701, South Africa. \\ E-mail: jcooper@adu.uct.ac.za \\ ${ }^{2}$ Istituto Nazionale per la Fauna Selvatica, via Ca' Fornacetta, 9, 1-40064 Ozzano Emilia, Bologna, Italy. \\ ${ }^{3}$ Department of Biology, University of Oulu, PL 3000, 90401 Oulu, Finland. \\ ${ }^{4}$ Seabird Research Group, BirdLife Malta, 57/28 Marina Court, Abate Rigord Street, Ta' Xbiex MSD12, Malta. \\ ${ }^{5}$ Institut Mediterrani d'Estudis Avançats, Miquel Marques 21, 07190 Esporles, Mallorca, Spain. \\ ${ }^{6}$ Hellenic Ornithological Society, 53 Emm. Benaki Str., 10681 Athens, Greece. \\ ${ }^{7}$ Sociedad Española de Ornitología/BirdLife, c/Melquiades Biencinto, 34, E 28053, Madrid, Spain.
}

\begin{abstract}
SUMMARY: A country-by-country review of seabird mortality from longline fishing in the Mediterranean Sea and in Macaronesian waters shows a paucity of data. Of 12 Mediterranean countries known to undertake longlining, seabird mortality is only reported for six: France, Greece, Italy, Malta, Spain and Tunisia. Seabird mortality from longlining has been reported from the Azores (Portugal) but not from the other Macaronesian Islands. Only for one country, Spain, is information on the levels of mortality available, suggesting that $4-6 \%$ of the local breeding population of Cory's shearwater Calonectris diomedea may be killed annually, a level considered unsustainable for the long-term persistence of colonies. Cory's shearwater is the most commonly affected species, although a number of Larus gull species are also being caught. There is insufficient knowledge to conclude whether any seabird species is at conservation risk within the region, but concern is expressed for Cory's shearwater. It is recommended that Mediterranean and Macaronesian countries conduct assessments of their longline fisheries and seabird mortality in terms of the Food and Agriculture Organization's International Plan of Action Seabirds. Regional fishery organisations, such as ICCAT and GFCM, should commence the collection of seabird mortality data. A "longline action plan" for the affected seabird species should be produced.
\end{abstract}

Key words: seabirds, longline fishing, conservation, Mediterranean, Macaronesia.

RESUMEN: Mortalidad de AVES MARINAS EN PALANGRES DEl MAR MEDITERRÁNEO E ISLAS MACARONESIAS: REVISIÓN Y PROPUESTAS DE FUTURO. - Este trabajo presenta una revisión de la escasa información disponible sobre mortalidad de aves marinas en las flotas palangreras del mar Mediterráneo y Macaronesia. De los 12 países mediterráneos que disponen de flota palangrera tan sólo 6 han aportado información sobre mortalidad de aves marinas: Francia, Grecia, Italia, Malta, España y Túnez. También se sabe que existe mortalidad de aves marinas en las islas Azores (Portugal) pero no en el resto de las islas de la Macaronesia. Tan sólo España dispone de información sobre niveles de mortalidad. Es posible que entre el 4-6\% de la población reproductora local de pardela cenicienta Calonectris diomedea muera en el palangre anualmente, un nivel que se considera insostenible para la persistencia a largo plazo de las colonias. La pardela cenicienta es la especie más afectada, aunque también se capturan gaviotas del género Larus. Aunque no se sabe lo suficiente como para concluir si alguna especie de ave marina está amenazada localmente por el palangre, se sugiere que la pardela cenicienta sí puede estarlo. Se recomienda que los países mediterráneos y macaronésicos lleven a cabo valoraciones de sus pesquerías de palangre y de la mortalidad de aves marinas en los términos de los planes internacionales de acción de la FAO. Las organizaciones pesqueras

*Received November 6, 2001. Accepted September 8, 2002. 
regionales, tales como la ICCAT y la GFCM, deberían comenzar a compilar información sobre mortalidad de aves marinas. Se debería redactar un plan de accción para las especies de aves marinas afectadas.

Palabras clave: aves marinas, pesca de palangre, conservación, mediterráneo, Macaronesia.

\section{INTRODUCTION}

In the last two decades it has been realised that longline fishing is not as "environmentally-friendly" a fishing method as it was first thought to be. Increasing evidence from many parts of the world's oceans and seas has shown that the incidental mortality of sharks, turtles and seabirds killed on longline hooks is a serious conservation concern (Spotila et al., 1996; Brothers et al., 1999; FAO, 1999a). The problem is best known for seabirds, especially for the albatrosses and petrels of the Southern Ocean (Brothers, 1991; Alexander et al., 1997; Croxall and Gales, 1998). However, seabirds of the northern hemisphere have not escaped, and high levels of mortality occur in both the northern Pacific and Atlantic Oceans, affecting primarily the larger procellariiform species and gulls (Cousins and Cooper, 2000; Cooper et al., 2000). On a global scale, mortality is greatest at higher latitudes, reflecting both the broad concentrations of longline fisheries and the distribution and abundance of albatrosses and petrels (procellariiforms), the species group most at risk (Brothers et al., 1999). However, longlining also takes place in warmer seas, such as the Mediterranean, where some species of petrels occur, although information on seabird mortality is generally less well known for these regions.

International communities have recognised the problem, and a number of efforts to address it are being undertaken (Cooper et al., 2001). At an intergovernmental level, in 1999 the Committee on Fisheries of the Food and Agriculture Organization of the United Nations (FAO) adopted an "International Plan of Action for Reducing Incidental Catch of Seabirds in Longline Fishing" (IPOASeabirds) that sets out a voluntary process for nations to follow to reduce seabird mortality in their longline fisheries (FAO, 1999b). A number of nations have recently negotiated an "Agreement on the Conservation of Albatrosses and Petrels" in terms of the Bonn Convention on the Conservation of Migratory Species of Wild Animals. In Arctic Seas, the inter-governmental Programme for the Conservation of Arctic Flora and Fauna (CAFF) has held workshops to consider how collaborative action can be applied to reducing seabird mortality (Bakken and Falk, 1998; Cooper et al., 2000). Procellariiform seabird researchers and managers have come together on several occasions in recent years in workshops to review the effects of longlining (Alexander et al., 1997; Cooper, 2000a). Non-governmental organisations have also been involved. In August 2000, the Seabird Conservation Programme of BirdLife International launched its global "Save the Albatross Campaign: Keep the World's Seabirds off the Hook" at the British Birdwatching Fair at Rutland Water, UK (Cooper, 2000b). It is intended that this campaign will be taken up by many of the BirdLife partners based in countries which undertake longline fishing.

We review what is known of seabird mortality from longline fishing in the Mediterranean Sea and in Macaronesian waters (Azores, Madeira, Canaries and Cape Verde) on a country-by-country basis, including distant-water fishing nations, and then attempt to estimate which seabird species occurring within this region are most seriously affected. Lastly, we set out how regional collaboration between Mediterranean and Macaronesian nations could lead to an improved situation for their seabirds.

\section{METHODS}

The information reviewed here has been obtained from published and unpublished sources, making use of appeals published in newsletters and over the internet, both via the Seabird Listserver and through direct contact. Contacts made at the 6th Mediterranean Symposium on Marine Birds, held in Benidorm, Spain in October 2000, have materially added to the data base.

\section{COUNTRY REVIEWS}

\section{Mediterranean Sea}

\section{Albania}

No information is available. 


\section{Algeria}

Algeria has undertaken pelagic longlining for broad-bill swordfish Xiphias gladius and northern bluefin tuna Thunnus thynnus in the Mediterranean since 1971 (Folsom, 1997). Nothing is known about seabird mortality.

\section{Bosnia and Herzegovina}

No information is available on longline fishing or on seabird mortality. This country has a marine coastline of only a few kilometres.

\section{Croatia}

Longline fishing is not known to take place (Folsom, 1997; Cooper and Muzinic, 1999).

\section{Cyprus}

Both demersal and pelagic longlining takes place. Nineteen vessels longlined for swordfish in 1994 (Folsom, 1997). No information is available on seabird mortality.

\section{Egypt}

No information is available (M. Baha El Din, in litt.).

\section{France}

Small-scale demersal longline fishing for hake Merluccius sp. is performed by France in the Gulf of Lions, although no information is available on seabird mortality (Brothers et al., 1999). Cory's Calonectris diomedea and Mediterranean or Balearic shearwaters have been reported killed by longlines in the Straits of Bonifacio, between Corsica (France) and Sardinia (Italy) (Thibault, 1993; JC. Thibault, in litt.).

\section{Greece}

Greece undertakes pelagic longlining for swordfish and tuna and demersal longlining for breams such as Dentex, Pagrus and Epinephalus (Folsom, 1997; Papaconstantinou, 2000). The demersal fleet is made up a large number of small coastal vessels. Individual reports from demersal longliners have been collected over the last 10 years of mortality of mainly Cory's shearwater (up to five birds on one line, and 30 in one year by one fishing vessel), but also of Audouin's gull Larus audouinii and the yellow-legged gull L. cachinnans, from Ithaki, Ionian Islands; the Gulf of Corinth; Cape Acritas, south-west Peloponnese; Chania, Crete; and Simi, Dodecanese Islands (Papaconstantinou, 2000). In contrast, no seabirds were seen to be killed by 240 pelagic longline sets for tuna and swordfish observed in the Aegean Sea as part of a turtle bycatch monitoring programme (A. Kapantagakis, in litt.). Cory's shearwaters have been reported killed by longlines in Crete (Thibault, 1993). In a long-term study at a breeding colony on an island offshore of Crete, two live and two dead birds were found with swallowed hooks and a further three hooks were found at nest entrances (D. Ristow, in litt.). Five of eight distant banding recoveries from this colony were reported as due to fishery by-catch.

Israel

Demersal longlining is undertaken by 300 small coastal vessels fishing for groupers and snappers (Folsom, 1997). No information is available on seabird mortality.

Italy

Italy operates small longliners that target swordfish, 700 of which are based in Sicily (Folsom, 1997). Additionally, thousands of small boats undertake mainly artisanal demersal longlining close inshore. Cory's shearwaters have been reported killed by longlines in the Straits of Bonifacio between Corsica (France) and Sardinia (Italy) and in Sicilian waters (Thibault, 1993). A. de Faveri (pers. comm. to N. Baccetti) observed ca. 10 Cory's shearwater corpses on a Sicilian beach with cut fishing lines emerging from their bills, thought to be due to pelagic longlining. Five to six Mediterranean shearwaters have been seen caught on a single longline at sea in Italian waters and a dead Audouin's gull was found entangled by a demersal longline hook and attached line in a breeding colony on Giglio Island near Elba in May 2001 by N. Baccetti.

A seabird rehabilitation centre at Livorno in the Ligurian Sea treated 42 hooked seabirds between 1988 and June 2000, of which most (based on information from other Mediterranean countries) are likely to have been caught on longlines. These 
species were Mediterranean shearwaters Puffinus yelkouan (2), Balearic shearwater Puffinus mauretanicus (1), yellow-legged gulls (21), black-headed gulls Larus ridibundus (5), Mediterranean gull $L$. melanocephalus (1) and northern gannets Morus bassanus (7) (C. Marzi, pers. comm. to N. Baccetti). The absence of hooked Cory's shearwaters at the rehabilitation centre may be due to their relative rarity in the region compared to the Puffinus shearwaters (M. Lambertini, in litt.).

\section{Lebanon}

No information is available.

\section{Libya}

In 1992-1994 five longliners fished for Northern Bluefin Tuna (Folsom, 1997). No information is available on seabird mortality.

\section{Malta}

Pelagic longline fishing targeting swordfish and northern bluefin tuna commenced in the early 1960s (Farrugia-Randon, 1995). The Maltese longlining fleet consists of some 75 "launches" and 344 "luzzus" (Busutill, 1993). From March to August 2000 an investigation by the Seabird Research Group of BirdLife Malta utilising questionnaires reported mortality from longlining of Cory's shearwaters (36, of a total of 63 birds, 57\%), Mediterranean shearwaters (8), yellow-legged gulls (6), black-headed gulls (6), Mediterranean gulls (4), northern gannet (1) and great cormorants Phalacrocorax carbo (2). Most birds were reported killed from lines set in the late afternoon or in the hour before sunrise. Few birds were caught on lines set during midday or at night. Most Cory's shearwaters were caught in June. In addition, small vessels undertaking trolling for tuna, bream Dentex dentex and other predatory fish reported 35 birds killed, of which 25 were Cory's shearwaters (71\%) and two Mediterranean shearwaters. The rest were yellow-legged gulls (2), Mediterranean gull (1), Sandwich terns Sterna sandvicensis (3) and black terns Chlidonias niger (2).

\section{Monaco}

No information is known for this country with an extremely small coastline.

\section{Morocco}

Longline fishing, including for swordfish and tuna, takes place from over a thousand small coastal vessels (Folsom, 1997), but nothing is known about seabird mortality.

\section{Palestine National Authority (Gaza)}

No information is available on longline fishing or on seabird mortality (I. Al-Atrash, pers. comm.).

\section{Slovenia}

No information is available on longline fishing or on seabird mortality (A. Sovinc, pers. comm.).

\section{Spain}

Spain undertakes both pelagic and demersal longlining in the Mediterranean, respectively directed at swordfish and tuna, and hake and breams of the genera Pagrus, Pagellus and Dentex (Folsom, 1997; Raymakers and Lynham, 1999; Valeiras and Camiñas, 2003; Belda and Sánchez, 2001). Longline fishing undertaken around the Columbretes (43 vessels) and Balearic Islands, in the Gulf of Valencia, has been reported to kill seabirds, primarily Cory's shearwaters and Audouin's and yellow-legged gulls, as well as Balearic shearwaters, northern gannets, a European shag Phalacrocorax aristostelis and a great skua Catharacta skua (Mayol, 1986; Aguilar, 1998; Sánchez and Belda, 2000a; Belda and Sánchez, 2001). During 1992-1998, 49 banded birds were reported from seven longline vessels fishing around the Columbretes, made up of 38 Cory's shearwaters ( 25 caught in 1997 alone when a trawler moratorium was in existence), nine Audouin's gulls and two yellow-legged gulls (Sánchez and Belda, 2000a; Belda and Sánchez, 2001). Most banded Cory's shearwaters were caught from May to June. Over half were adult birds (7+ years). In 1997 a report was made of 200 Cory's shearwaters killed by a single longline vessel in one day (Sánchez and Belda, 2000a).

Observations of 129 longline sets and hauls around the Columbretes in 1998 and 1999 by SEO/BirdLife resulted in 27 birds being reported killed, of which 18 (67\%) were Cory's shearwaters. An average seabird mortality of 0.69 birds $/ 1000$ hooks was recorded for demersal vessels, and 0.25 birds/10000 hooks for pelagic vessels in 1998 and 
0.16 birds/1000 hooks for demersal vessels in 1999 (Belda and Sánchez, 2001). It was estimated that the Columbretes longline fishery killed annually 4371867 Cory's shearwaters, and the Balearic fishery ca. 1300, out of a population of $c a .11000$ breeding pairs, or $4-6 \%$ of the local breeding population (Aguilar, 1998; Belda and Sánchez, 2001). Between 72 and 311 Audouin's gulls (1\% of the local population) were estimated to be killed annually around the Columbretes Islands.

Most mortality occurred around sunrise in demersal fisheries, and in mid-afternoon to dusk in pelagic fishing, times which coincided with peak numbers of birds attending vessels. Birds were rarely caught at night by demersal longliners (three Cory's shearwaters) and only in moonlight conditions (Belda and Sánchez, 2001). Bait loss occurred mainly to Cory's shearwaters ( $77 \%$ of occurrences) and was most prevalent around sunrise and from mid-afternoon to dusk. The minimum estimate of bait loss was 10.9 baits/1000 hooks (Sánchez and Belda, 2000b).

Mitigation measures practiced in the Columbretes fishery are voluntary and consist of: (i) towing a line (without streamers) about 30-50 m behind the vessel, which appears not to be very efficient at scaring away birds; and (ii) setting longlines at night, which appears to be highly efficient at reducing both seabird mortality and bait loss. For this reason use of a bird-scaring line with streamers and mounted on a pole is recommended, along with a restriction to night-setting (Belda and Sánchez, 2001). There is no formal observer programme with this fishery. However, since 1998 the Secretary de Pesca del Ministerio de Agricultura y Pesca and the Consellaria de Medio Ambiente de la Generalitat Valenciana have funded several projects to study the problem, including a one-year observation programme that commenced in April 2000. This work has been undertaken by SEO/BirdLife.

From July 1999 to August 2000, 554 sets (1.57 million hooks) from 18 Spanish pelagic and semipelagic longliners in the western Mediterranean were observed by the Spanish Oceanographic Institute. Twenty-one birds (nine Cory's shearwaters, one northern gannet and 11 yellow-legged gulls) were reported caught, giving a catch rate of 0.013 birds/1000 hooks (Valeiras and Camiñas, 2003). Nothing is known about seabird mortality from Spanish pelagic longline vessels operating elsewhere in the Mediterranean Sea, although it is assumed to occur (Raymakers and Lynham, 1999).
Information on causes of mortality of Audouin's gulls in a breeding colony in the Ebro Delta collected over nine March-July breeding seasons (19922000) showed that $6.2 \%$ (35 birds out of 569 found dead) died as result of fishery interactions, including with hooks (Oro, 1996; D. Oro, unpublished data).

Syria

No information is available.

\section{Tunisia}

Tunisia has undertaken pelagic longlining for swordfish and tuna in the Mediterranean since 1982; in 198820 vessels operated (Folsom, 1997). Cory's shearwaters have been reported killed by longlines in Tunisia (Thibault, 1993; D. Ristow, in litt.).

\section{Turkey}

Small coastal vessels longline for swordfish in the Mediterranean, setting 200 hooks on 12-km lines (Folsom, 1997). Nothing is known of seabird mortality.

\section{Yugoslavia (Montenegro)}

No information is available on longline fishing or on seabird mortality.

\section{Distant-water fishing nations}

Japan, Korea and Taiwan, and probably vessels registered to a number of "flag of convenience" countries, have undertaken pelagic longlining for swordfish and tuna in the Mediterranean (Folsom, 1997; Brothers et al., 1999; Greenpeace, 2000) but no information is available on seabird mortality.

\section{Macaronesian Islands}

\section{Azores (Portugal)}

Longlining for swordfish and tuna has been performed around the Azores by Portuguese vessels since the mid-1980s; four vessels were built for this fishery in 1991 (Folsom, 1997). Demersal longlining for blackspot bream Pagellus bogarevo also occurs (Brothers et al., 1999). A presumed Cory's shearwater and three gulls were reported killed by 150 sets (half a million hooks) from a demersal research longliner during the period 1993-1997 
(Brothers et al., 1999; A. Silva, in litt.). An analysis of logbooks from 1993 and a turtle observer programme operating in 1998-1999 in the pelagic swordfish fishery have not revealed bird mortality, suggesting that any such mortality is likely to be low, possibly due to the large hooks used, in comparison to the demersal fishery (A. Silva, in litt.).

\section{Madeira and the Selvagen Islands (Portugal)}

Longlining for swordfish and tuna has been performed around Madeira and the Selvagens by Portuguese vessels since the mid-1980s (Folsom, 1997; D. Camara, in litt.). Longlining for Black Scabbardfish Aphanopus carbo and sharks also takes place (Brothers et al., 1999). Seabird mortality by longlining is not mentioned by Le Grand et al. (1984) or Zino and Biscoito (1994) in their reviews of the threats facing seabirds in this archipelago. If it occurs, seabird mortality is thought to be only at a low level (D. Camara, in litt.).

\section{Canary Islands (Spain)}

Longliners based in mainland Spain are thought to fish in the vicinity of the Canary Islands (Folsom, 1997). No information is available on seabird mortality from longlining, which is not mentioned as a threat to seabirds by Le Grand et al. (1984) in their review of the conservation of seabirds in the Macaronesian Islands. Hooked yellow-legged gulls have been seen dead and alive in breeding colonies, but these are thought to be due to recreational rather than to longline fishing. Cory's shearwaters, of the local subspecies $C$. $d$. borealis, have been seen trying to seize artificial lures used in sport fishing for pelagic species, but are not thought to be affected seriously by longlining (A. Martín, in litt.).

\section{Cape Verde Islands}

Longline fishing takes place for swordfish (in small quantities) and tuna, primarily yellowfin or albacore Thunnus albacares, as well as for "bottom fish" (Folsom, 1997). In the 1980s Spanish longliners were licensed to fish within Cape Verde's 200-nautical mile Exclusive Economic Zone. No information is available on seabird mortality from either artisanal or commercial fishing vessels (C.J. Hazevoet, in litt.), which is not mentioned by Le Grand et al. (1984) or Hazevoet (1994) in their reviews of seabird conservation in the Cape Verde Islands.

\section{DISCUSSION}

Very little is known about seabird mortality from longlining fishing in the Mediterranean Sea and in the waters of the Macaronesian Islands. Compared to more isolated parts of the world's seas, such as the Southern Ocean where detailed information is available (Alexander at al., 1997; Brothers et al., 1999), this is somewhat surprising. Longline fishing is undertaken by at least 12 of the political entities bordering the Mediterranean, but seabird mortality from longlining has only been reported for the waters of six: France, Greece, Italy, Malta, Spain and Tunisia. Of these, quantitative information on rates of mortality is available only for Spain (Valeiras and Camiñas, 2003; Belda and Sánchez, 2001). No information is available for the Asian distant-water fishing fleets. Longlining takes place from all four island groups that make up the Macaronesian Islands, but seabird mortality has only been reported for the Azores, politically part of Portugal, and that not from a commercial fishery.

In terms of the FAO's IPOA-Seabirds, countries causing seabird mortality by longlining are encouraged to produce their own National Plans of Action, reporting on progress to the FAO's Committee on Fisheries in 2001. As far as is known, no Mediterranean or Macaronesian country has as yet taken this step. It is recommended that those countries where seabird mortality from longlining has been reported should now conduct assessments to ascertain whether NPOA-Seabirds are required.

A number of (but not all) Mediterranean and Macaronesian countries are members of the International Commission for the Conservation of Atlantic Tunas (ICCAT). However, although ICCAT has a Sub-Committee on By-Catch it does not currently collect information on seabird mortality through its observer and reporting schemes, although it now does so for sharks (Anon., 1996). It is recommended that member countries request that ICCAT commence the collection and analysis of seabird bycatch data. The General Fisheries Council for the Mediterranean (GFCM) is another international body that could be requested to collect seabird bycatch data. Such regional cooperation between countries is recommended by the FAO's International Plan of Action - Seabirds (Clauses 19 and 20; FAO, 1999b).

As elsewhere in the world (Brothers et al., 1999), the species affected are mostly procellariiform tubenoses and gulls. The species likely to be taken in 
the greatest numbers in the Mediterranean is Cory's shearwater, which formed $57 \%$ of the mortality in the small Maltese study and $67 \%$ in Spanish waters (Belda and Sánchez, 2001). The total Mediterranean population for this species has been estimated as 50000-80000 breeding pairs located at 103 known colonies belonging to eight countries (Zotier et al., 1992; Thibault, 1993). Lack of information makes it impossible at this stage to estimate what proportion of this population may be killed annually by longliners, but it is to be noted that $4-6 \%$ of the local breeding population was estimated to be killed annually in the Spanish study (Belda and Sánchez, 2001). If this level of mortality persists throughout the Mediterranean where the species occurs, then it would seem that the species is at serious risk. Cory's shearwaters migrate to the North and South Atlantic in the non-breeding season (Cramp and Simmons, 1977), where they must be at least potentially at risk to longliners. However, they have not as yet been reported killed in South African waters (Barnes et al., 1997; P.G. Ryan, pers. comm.) or off the Atlantic coast of South America (Neves and Olmos, 1998; Olmos et al., 2001). Information on population trends of Cory's shearwaters in the Mediterranean is incomplete, with some studied populations appearing stable, others in decline (Zotier et al., 1992). This species faces a number of other humancaused threats (e.g. Thibault, 1993; Borg and Cachia-Zammit, 1998).

Before limited resources are directed to conservation efforts it is desirable to assess the scale of the threat. But much more needs to be known about the levels of seabird mortality from longline fishing in the Mediterranean Sea and Macaronesian waters before such an assessment can be made. The challenge is to start collecting the necessary data now, before species such as Cory's shearwater become threatened with colony extinctions. The first step should be to hold a dedicated workshop to assess the problem of longline fishing in the Mediterranean and around the Macaronesian Islands, and to set priorities for data-gathering, research and management. The workshop could usefully consider all the species of seabirds known to be affected, including those with relatively small and/or endemic populations for which conservation concern has already been expressed by the production of species action plans, such as the Balearic shearwater and Audouin's gull (Heredia et al., 1996; BirdLife International, 1999; Gallo-Orsi, 2003). The workshop could lead to the production of a "longline action plan" for the seriously affected species to be adopted by all the Mediterranean and Macaronesian countries in whose waters the various species occur. The workshop and action plan could be held and produced under the combined auspices of the Mediterranean Marine Bird Association and BirdLife International (both through its Seabird Conservation Programme and its Mediterranean partners), as part of the global "Save the Albatross Campaign".

\section{ACKNOWLEDGEMENTS}

The financial and logistic support of the African Seabird Group, the Conselleria de Medio Ambiente de la Generalitat Valenciana, the Royal Society for the Protection of Birds, the Secretaria de Pesca del Ministerio de Agricultura y Pesca, Spain, the University of Cape Town, and the World Conservation Union (IUCN) is gratefully acknowledged. We thank those colleagues who have helped with information and ideas.

\section{REFERENCES}

Aguilar, J.S. - 1998. Biología y conservación de la Pardela Balear Puffinus mauretanicus. Documents Tècnics de Conservació (II ep) 2. Govern Balear, Palma de Mallorca.

Alexander, K., G. Robertson and R. Gales. - 1997. The incidental mortality of albatrosses in longline fisheries. Australian Antarctic Division, Kingston.

Anon. - 1996. International Commission for the Conservation of Atlantic Tunas (ICCAT). Shark News, 8: 2.

Bakken, V. and K. Falk. (eds.). - 1998. Incidental take of seabirds in commercial fisheries in the Arctic countries. Conservation of Arctic Flora and Fauna Tech. Rpt, No. 1.

Barnes, K.N., P.G. Ryan and C. Boix-Hinzen. - 1997. The impact of the hake Merluccius spp. longline fishery of South Africa on procellariiform birds. Biol. Conserv., 82: 227-234.

Belda, E.J. and A. Sánchez. - 2001. Seabird mortality on longline fisheries in the western Mediterranean: factors affecting bycatch and proposed mitigating measures. Biol. Conserv., 98: 357-363.

BirdLife International. - 1999. European Union Species Action Plan Balearic shearwater (Puffinus mauretanicus). Unpublished report to the European Commission. 50 pp.

Borg, J.J. and R. Cachia-Zammit. - 1998. Monitoring Cory's shearwater Calonectris diomedea colonies in a hostile environment Malta. In: J. Walmsley, J. Sultana, V. Goutner and A. El Hili (eds.), Ecologie des oiseaux marins et gestion intégrée du littoral en Méditerranée. Quatrième Symposium Méditerranéen des Oiseaux Marins. Hammamet 11-16 Avril 1995, pp. 31-47. Association "Les Amis des Oiseaux" \& Medmaravis, Tunis.

Brothers, N. - 1991. Albatross mortality and associated bait loss in the Japanese longline fishery. Biol. Conserv., 55: 255-268.

Brothers, N.P., J. Cooper and S. Løkkeborg. - 1999. The incidental catch of seabirds by longline fisheries: worldwide review and technical guidelines for mitigation. FAO Fisheries Circular No. 937. $100 \mathrm{pp}$.

Busutill, C. - 1993. The fishing industry. In: Options mediterraneenes. Serie B: Etudes et Recherches No. 7. Food, Agriculture, Fisheries and the Environment. CIHEAM, Malta.

Cooper, J. (ed.). - 2000a. Albatross and Petrel Mortality from Longline Fishing International Workshop, Honolulu, Hawaii, 
USA, 11-12 May 2000. Report and presented papers Mar. Orn., 28: $153-190$.

Cooper, J. - 2000b. Keeping albatrosses off the hook. Brit. Birds, 93: $260-262$

Cooper, J., J.P. Croxall and K.S. Rivera. - 2001. Off the hook? Initiatives to reduce seabird by-catch in longline fisheries. In: E.F. Melvin and J.K. Parrish (eds.), Seabird by-catch: trends, roadblocks, and solutions, pp. 9-32. University of Alaska Sea Grant, Fairbanks.

Cooper, J., E. Dunn, D.W. Kulka, K.H. Morgan and K.S. Rivera. 2000. Addressing the problem: seabird mortality from longline fisheries in the waters of Arctic countries. In: J. Chardine, J. Porter and K. Wohl (eds), Workshop on Seabird Incidental Catch in the Waters of Arctic Countries: Report and Recommendations, pp. 9, 33-42, 61-65. Conservation of Arctic Flora and Fauna Technical Report No. 7.

Cooper, J. and J. Muzinic. - 1999. Ribolov parangalima peca morske ptice. Hrvatska Vodoprivreda, 8(78): 62-66. [in Croatian].

Cousins, K. and J. Cooper. - 2000. The population biology of the Black-footed Albatross in relation to mortality caused by longline fishing. Western Pacific Regional Fishery Management Council, Honolulu.

Cramp, S. and K.E.L. Simmons. (eds.). - 1977. The birds of the western Palearctic, Vol. 1. Oxford University Press, Oxford.

Croxall, J.P. and R. Gales. - 1998. An assessment of the conservation status of albatrosses. In: G. Robertson and R. Gales (eds.), Albatross biology and conservation, pp. 46-65. Surrey Beatty \& Sons, Chipping Norton.

FAO. - 1999a. Report of the Consultation on the Management of Fishing Capacity, Shark Fisheries and Incidental Catch of Seabirds in Longline Fisheries. Rome, Italy, 26-30 October 1998. FAO Fish. Rep., 595: 1-122.

FAO. - 1999b. International Plan of Action for Reducing Incidental Catch of Seabirds in Longline Fisheries. International Plan of Action for the Conservation and Management of Sharks. International Plan of Action for the Management of Fishing Capacity. Food and Agriculture Organization of the United Nations, Rome.

Farrugia-Randon, S. - 1995. The fishing industry in Malta. Past, present and future. PIN Publications, Pieta, Malta.

Folsom, W.B. - 1997. World swordfish fisheries. An analysis of swordfish fisheries, market trends, and trade patterns. Past-present-future. Vol. II. Africa and the Middle East. Vol. VI. Western Europe. National Marine Fisheries Service, Silver Spring.

Gallo-Orsi, U. - 2003. Species Action Plans for the conservation of seabirds in the Mediterranean Sea: Audouin's gull, Balearic shearwater and Mediterranean shag. Sci. Mar., 67(Suppl. 2): $47-55$

Greenpeace. - 2000. Eradicating pirate fishing. A study of the current status of tuna and tuna-like fish stocks in the Atlantic Ocean and Mediterranean Sea. Greenpeace International.

Hazevoet, C.J. - 1994. Status and conservation of seabirds in the Cape Verde Islands. BirdLife Conserv. Ser., 1: 279-293.

Heredia, B., L. Rose and M. Painter. (eds.). - 1996. Globally threatened birds in Europe. Action plans. Council of Europe Publish- ing, Strasbourg.

Le Grand, G., K. Emmerson and A. Martin. - 1984. The status and conservation of seabirds in the Macaronesian Islands. Internat. Council Bird Preserv. Tech. Publ., 2: 377-391.

Mayol, J. - 1986. Human impact on seabirds in the Balearic Islands. In: MEDMARAVIS and X. Monbailliu (eds.), Mediterranean marine avifauna. Population studies and conservation, pp. 379396. Springer-Verlag, Berlin.

Neves, T. and F. Olmos. - 1998. Albatross mortality in fisheries off the coast of Brazil. In: G. Robertson and R. Gales (eds.), Albatross biology and conservation, pp. 214-219. Surrey Beatty \& Sons, Chipping Norton.

Olmos, F., G.C.C. Bastos, T.S. Neves and J. Cooper. - 2001. Pesca no céu. A morte de aves em espinhéis no Brasil. Ciência Hoje, 29: 24-32

Oro, D. - 1996. Are migrating Peregrine Falcons Falco peregrinus a threat to breeding Audouin's gull Larus audouinii at the Ebro Delta? Colonial Waterbirds, 19: 270-272.

Papaconstaninou, C. - 2000. [The longlining problem\}. Oeonos, 14. [in Greek].

Raymakers, C. and J. Lynham. - 1999. Slipping the net: Spain's compliance with ICCAT recommendations for swordfish and bluefin tuna. TRAFFIC International, Cambridge.

Sánchez, A. and E.J. Belda. - 2000a. Incidental catch of seabirds in longline fisheries around Columbretes Islands, Mediterranean Sea (Spain). In: P. Yésou. and J. Sultana (eds.), Monitoring and conservation of birds, mammals and sea turtles of the Mediterranean and Black Seas, pp. 133-134. Environment Protection Department, Floriana, Malta.

Sánchez, A. and E.J. Belda. - 2000b. Bait loss in long-lines due to scavenging birds in the northwestern Mediterranean: the effect of time of setting. 6th Mediterranean Symposium on Seabirds. Conference on Fisheries, Marine Productivity and Conservation of Seabirds. Benidorm (Alicante, Spain), 11-15th October, 2000. Programme summaries of plenary conferences, oral communications and posters. p. 18.

Spotila, J.R., A.E. Dunham, A.J. Leslie, A.C. Steyermark, P.T. Plotkin and F.V. Paladino. - 1996. Worldwide population decline of Dermochelys coriacea: are Leatherback Turtles going extinct? Chelonian Conserv. Biol., 2: 209-222.

Thibault, J-C.- 1993. Breeding distribution and numbers of Cory's shearwater (Calonectris diomedea) in the Mediterranean. In: J.S. Aguilar, X. Monbailliu and A.M. Paterson (eds.), Status and conservation of seabirds. Ecogeography and Mediterranean Action Plan, pp. 25-35. Sociedad Española de Ornitología, Madrid.

Valeiras, J. and J.A. Camiñas. - 2003. The incidental capture of seabirds by Spanish drifting longline fisheries in the western Mediterranean Sea. Sci. Mar., 67 (Suppl. 2): 65-68.

Zino, F. and M. Biscoito. - 1994, Breeding seabirds in the Madeira Archipelago. BirdLife Conserv. Ser., 1: 172-185.

Zotier, R., J-C. Thibault, and I. Guyot. - 1992. Known population and distribution of cormorants, shearwaters and storm petrels in the Mediterranean. Avocetta, 16: 118-126. 